\title{
Assessing the current and future urban heat island of Brussels
}

\author{
D. Lauwaet ${ }^{\mathrm{a}, *}$, K. De Ridder $^{\mathrm{a}}$, S. Saeed ${ }^{\mathrm{b}}$, E. Brisson ${ }^{\mathrm{b}, \mathrm{c}}$, F. Chatterjee $^{\mathrm{b}}$, N.P.M. van Lipzig ${ }^{\mathrm{b}}$, \\ B. Maiheu ${ }^{a}$, H. Hooyberghs ${ }^{a}$ \\ a Vlaamse Instelling voor Technologisch Onderzoek (VITO), Boeretang 200, $2400 \mathrm{Mol}$, Belgium \\ ${ }^{\mathrm{b}}$ Physical and Regional Geography Research Group, Department of Earth and Environmental Sciences, K.U. Leuven, Celestijnenlaan 200 E, 3001 Heverlee, Belgium \\ ${ }^{\mathrm{c}}$ Institute for Atmospheric and Environmental Sciences, Goethe University Frankfurt, Grueneburgplatz 1, RuW, 60323 Frankfurt am Main, Germany
}

\section{A R T I C L E I N F O}

\section{Article history:}

Received 27 January 2015

Revised 12 November 2015

Accepted 25 November 2015

\section{Keywords:}

Belgium

Brussels

Climate change

Downscaling

Urban heat island

UrbClim model

\begin{abstract}
A B S T R A C T
This study examines the urban heat island (UHI) of Brussels, for both current (2000-2009) and projected future (2060-2069) climate conditions, by employing very high resolution $(250 \mathrm{~m})$ modelling experiments, using the urban boundary layer climate model UrbClim. Meteorological parameters that are related to the intensity of the UHI are identified and it is investigated how these parameters and the magnitude of the UHI evolve for two plausible trajectories for future climate conditions. UHI intensity is found to be strongly correlated to the inversion strength in the lowest $100 \mathrm{~m}$ of the atmosphere. The results for the future scenarios indicate that the magnitude of the UHI is expected to decrease slightly due to global warming. This can be attributed to the increased incoming longwave radiation, caused by higher air temperature and humidity values. The presence of the UHI also has a significant impact on the frequency of extreme temperature events in the city area, both in present and future climates, and exacerbates the impact of climate change on the urban population as the amount of heat wave days in the city increases twice as fast as in the rural surroundings.
\end{abstract}

(C) 2015 Elsevier B.V. All rights reserved.

\section{Introduction}

The continuous growth of urban population has led to an increasing amount of interdisciplinary research focussing on urban climate and the effects of urbanization at different scales (Arnfield 2003). The most prominent phenomenon is the fact that urban areas are generally warmer than their rural surroundings, the so-called urban heat island (UHI). In particular, cities experience higher air temperatures than rural areas, with night-time temperature differences up to $10{ }^{\circ} \mathrm{C}$ under favourable conditions (Landsberg, 1981; Oke, 1997). The UHI is caused by the increased heat capacity of cities, anthropogenic heat sources and the imperviousness of urban surfaces which inhibit evaporative cooling (Oke et al., 1991; Masson, 2006; Lynn et al., 2009). Because of the UHI increment, cities are particularly vulnerable to heat waves, with higher heat-related excess mortalities (Gabriel and Endlicher, 2011; Dousset et al., 2010).

Several observational studies have indicated that the magnitude of the UHI is strongly influenced by meteorological conditions. Bornstein (1968) and Gedzelman et al. (2003) studied the UHI of New York City and found that it was most pronounced on calm, dry, clear nights during which a strong nocturnal inversion could form over the countryside. They found a strong correlation between the UHI and the cloud cover, wind speed, wind direction and surface temperature

\footnotetext{
* Corresponding author.

E-mail address: dirk.lauwaet@vito.be (D. Lauwaet).
} 
inversion. Similar results were obtained for the cities of Athens and Thessaloniki in Greece, which showed that the largest UHI values were reached during clear nights with low humidity and anticyclonic conditions (Kassomenos and Katsoulis, 2006; Giannaros and Melas, 2012). The development of a sea breeze had a negative effect on UHI values. Also in Seoul (South Korea), the magnitude of the UHI was found to relate to wind speed and cloud cover, with the weakest UHI development during precipitation days (Kim and Baik, 2005; Lee and Baik, 2010). There, the UHI was stronger during week days, due to extra anthropogenic heat releases.

During the last years, increasingly sophisticated urban parameterizations are used to improve the representation of urban surfaces in regional and global climate models, in order to understand urban climate and its interactions with climate change. This is highly relevant, since climate projections indicate that in the future, cities may become more often exposed to extreme heat stress (IPCC, 2012). A lot of these urban surface energy balance models are compared by Grimmond et al. (2010, 2011), who conclude that simple models can perform as well as complex ones, and parameter values need to be carefully chosen for each specific city.

Studies with global climate models coupled to urban surface schemes indicate that urban and rural areas respond similarly to climate change, hence keeping UHI values more or less constant, although the number of extreme hot nights increases stronger in the cities (Fischer et al., 2012; Oleson, 2012). However, because of the coarse resolution of global climate models, they may not capture mesoscale or local features and feedbacks, that are important for UHI development (Hamdi et al., 2013). It should also be mentioned that these results are for conditions where the urban areas are static, that is, urban extent and properties do not change in the future.

Therefore, regional climate models with increasingly high resolutions are used to downscale the global climate scenarios. McCarthy et al. (2012) applied a $25 \mathrm{~km}$ resolution to study the UHIs of several cities in the UK under an A1B scenario. They found that the UHIs remained constant but caused the number of heat waves to be twice as high in cities, and the number of extreme hot nights to be even five times higher. In a study on both urban expansion and climate change with a $2 \mathrm{~km}$ resolution mesoscale model, Argüeso et al. (2013) found a strong effect on nocturnal temperatures due to urbanisation, which enhanced the climate change signal at local scales in Sydney (Australia). In a model set-up that is more or less similar to the one in this study, Kusaka et al. (2012) used a model resolution of $3 \mathrm{~km}$ to simulate the summer month of August for 10 consecutive years in the present (2000-2009) and the future (2070-2079) in a study over the largest urban areas in Japan. They also reported constant UHI values under warmer future conditions.

But even a model resolution of a few $\mathrm{km}$ is not enough to resolve all urban-scale features, for which a horizontal spatial resolution of the order of a kilometre or even higher is required. At this resolution mesoscale models become exceedingly slow because of numerical stability constraints, i.e. shorter time steps are required, so long model integrations are difficult to achieve. A method is proposed by Lemonsu et al. (2013) that projects the global climate at the regional scale with dynamical and statistical techniques, and then simulates the local scale with an offline urban model with a resolution of $1 \mathrm{~km}$. They reported a decrease of the UHI of Paris by the end of the century under A1B and A2 scenarios due to a stronger increase in rural temperatures caused by soil dryness in summer. The same effect is found by Hamdi et al. (2013) in their study of the Brussels UHI, in which they applied a more sophisticated method to achieve $1 \mathrm{~km}$ resolution results, involving an offline boundary layer scheme.

Our work builds on the research mentioned above by applying a horizontal model resolution of $250 \mathrm{~m}$, that is unprecedented for this kind of study, in our dynamically downscaling experiment over Brussels (Belgium). This high resolution has an important added value when assessing the heat exposure of inhabitants of the city, or identifying areas where people are most at risk, for which a map with a resolution of several kilometres makes little sense. To achieve this, the urban boundary layer climate model UrbClim (De Ridder et al., 2015) is used, which takes into account advection and feedback processes regarding air temperatures and humidity between the urban surface and the atmosphere, that cannot be included in studies with offline surface schemes. The goal of this study is to assess the current UHI of Brussels, define the meteorological parameters that play a role in its formation, and to investigate how these parameters and the magnitude of the UHI evolve for two plausible trajectories for future climate conditions: Representative Concentration Pathways (RCPs) 4.5 and 8.5.

The remainder of this paper is organized as follows. In Section 2, both the urban boundary layer climate model and the regional climate model, which provides the large-scale meteorological boundary data, are described. This section further provides an overview of all the input datasets and the experiment setups. Section 3 presents the results and discussions of this research, while conclusions are drawn in Section 4.

\section{Numerical models and experiment setup}

\subsection{The UrbClim model}

The model simulations in this study are performed with the urban boundary layer climate model UrbClim, designed to cover individual cities and their nearby surroundings at a very high spatial resolution (De Ridder et al., 2015). UrbClim consists of a land surface scheme containing simplified urban physics, coupled to a 3-D atmospheric boundary layer module. The latter is tied to synoptic-scale meteorological fields through the lateral and top boundary conditions, to ensure that the synoptic forcing is properly taken into account. The land surface scheme is based on the soil-vegetation-atmosphere transfer scheme of De Ridder and Schayes (1997), but is extended to account for urban surface physics. This urbanisation is 
accomplished in a rather simple way, by representing the urban surface as a rough impermeable slab, with appropriate values for the albedo, emissivity, thermal conductivity and volumetric heat capacity. The main feature of the extension of the scheme is the inclusion of a parameterization of the inverse Stanton number, which is known to be much higher in urban areas (Kanda et al., 2007; De Ridder et al., 2012).

While most other recent urban surface exchange models (e.g. Ikeda and Kusaka, 2010; Masson, 2000; Oleson et al., 2008) provide some canopy level detail, by decomposing the urban fabric into roof, wall and road facets, we have chosen to establish UrbClim on the simpler inverse Stanton number (bulk) approach, for several reasons. For one, urban canopy models need to specify transfer coefficients between the building facets and the canopy air. Many models, also recent ones, rely on fairly ancient parameterizations, e.g., by Jürges (1924) (used in, e.g., Ikeda and Kusaka, 2010), or Rowley et al. (1930) (used in, e.g., Masson, 2000; Oleson et al., 2008). Whereas these wall transfer coefficients were established by means of scale experiments, the Stanton-based heat transfer coefficients in UrbClim are obtained from a series of real-world experiments that we conducted on actual cities, using remotely sensed surface thermal infrared temperature (De Ridder, 2006; De Ridder et al., 2008; De Ridder et al., 2012). While doing so entails disregarding certain physical processes occurring within the urban canopy, our approach is based on observations from actual urban areas, rather than that it has to rely on scale model experiments. Moreover, it has been shown that the use of the inverse Stanton number framework is consistent with Monin-Obukhov similarity theory (Kanda et al., 2007).

The land surface scheme in UrbClim takes part of its input variables (wind speed, temperature and specific humidity close to the surface) from values simulated in the atmospheric boundary layer model, a basic 3-D model of the lower atmosphere, extending to a height of a few kilometres. This model is represented by conservation equations for horizontal momentum (considering zonal and meridional wind speed components $\mathrm{u}$ and $\mathrm{v}$, respectively), potential temperature, specific humidity, and mass (involving the vertical wind speed component w). Pressure fields are not calculated internally, but prescribed from a large-scale host model from which UrbClim receives its boundary conditions, hence only the synoptic-scale pressure gradient is accounted for. By doing so we avoid the complexities associated with a full mesoscale meteorological model. More importantly, it allows the use of much longer time increments in the numerical solver, and a lower model top (since no absorbing layer is required to damp gravity waves), which makes the model much faster. The specification from the large-scale driving model of the lateral and top boundary conditions, the synoptic-scale pressure gradient, and the downwelling radiation and precipitation fluxes - required by the land surface scheme - allows to account for the effect of synoptic weather on local climate, and defines the nesting of our urban boundary layer climate model within the large-scale host model. By doing so, UrbClim ignores the possible impact and feedback effect resulting from the spatial variability of the downwelling longwave radiation, which is addressed in Appendix A.

Terrain elevation data are taken from the GMTED2010 Dataset (Danielson and Gesch, 2011), which has a global coverage and is freely available. The spatial distribution of land cover types, needed for the specification of required land surface parameters, is taken from the CORINE land cover data for Europe (European Commission 1994). The percentage urban land cover is specified using the Urban Soil Sealing raster data files distributed by the European Environment Agency. Maps of vegetation cover fraction are obtained from the Normalized Difference Vegetation Index (NDVI) acquired by the MODIS instrument on-board the TERRA satellite platform. Vegetation cover fraction is specified as a function of the NDVI using a linear relationship proposed by Gutman and Ignatov (1998), and then interpolated to the model grid. Model grid cells featuring exclusively non-urban land use types are divided into vegetation and bare soil (the complementary fraction). In the case of grid cells containing urban land use, the urban fraction as derived from the Soil Sealing data takes precedence over the NDVI-based fractional vegetation cover data in case both sum to over $100 \%$. In case they sum to less than that, the remaining fraction is assigned to bare soil. Note that even though the parameter space is fixed for each land cover type in the model, spatial heterogeneity is assured by the spatial variability of the soil sealing and vegetation cover fractions of a grid cell, which define the effective roughness length of a grid cell through the inverse Stanton number framework.

Each of the surface types within a grid cell has its own energy balance and corresponding temperature, although the model employs aggregated values for both the aerodynamic and the thermal roughness length parameters. The reason for doing so is that we do consider model applications with spatial resolutions of the order of a few hundred metres, and it is fair to assume that on this scale turbulent intensities, as represented by the aerodynamic resistances, are fairly homogenous. The urban surface cover has an associated very low thermal roughness length which strongly inhibits the turbulent transfer of heat from the urban substrate to the atmosphere, so that a relatively large share of the available radiant surface energy flux is converted to storage heat rather than to turbulent sensible heating of the atmosphere. This, together with the typically high values of thermal inertia of urban materials, leads to the large storage heat flux values typically observed (or estimated as a residual of the surface energy balance) over urban areas (Piringer et al., 2007).

The urban substrate is represented as a massive slab, which is discretised in six vertical layers, and its specific volumetric heat capacity $\left(2 \times 10^{6} \mathrm{~J} \mathrm{~m}^{-3} \mathrm{~K}^{-1}\right)$ and thermal conductivity $\left(2 \mathrm{~W} \mathrm{~m}^{-1} \mathrm{~K}^{-1}\right)$ values are in line with values found in the literature for urban areas (see, e.g., Oke, 2002; Pielke, 2002). Evaporation from the urban surface is included by implementing a fractional surface wetness parameter, which accounts for the amount of water stored on the urban substrate, calculated as the difference between precipitation on the urban fraction and evaporation of the stored water. The maximal fraction of wet surface is set as 0.14 , with a maximum storage capacity of $1.17 \mathrm{~kg} \mathrm{~m}^{-2}$. Both parameters have been estimated recently by Wouters et al. (2015). The evolution of the temperature profile in the soil is calculated using the same heat diffusion equations as those used for the urban slab. The main difference is that, for soil, the volumetric heat capacity and thermal conductivity are functions of soil moisture content, as in De Ridder and Schayes (1997). Water transport in the soil is described by 
means of Richards' equation (Garratt, 1992), accounting for infiltration of rain water in the soil and the uptake of soil water by plant roots. The reader is referred to De Ridder and Schayes (1997) for more details.

\subsection{The COSMO-CLM model}

The regional climate model COSMO-CLM is the product of a joint effort from the Consortium for Small-scale Modelling (COSMO) and the Climate Limited-area Modelling Community (CLM-Community). These two groups, encompassing national weather services and climate research centres, maintain a common model for both operational weather prediction and regional climate simulations. A detailed description and full documentation of the model is provided by Doms (2011). COSMO-CLM is a non-hydrostatic model that allows applications on a wide range of spatial scales. In this study, we use COSMO-CLM version 4.8. This model version, along with earlier versions, has been extensively evaluated by e.g. Jaeger et al. (2008), Meissner et al. (2009) and Dobler and Ahrens (2011).

Land surface processes are parameterized through the soil module TERRA_ML (Grasselt et al., 2008). The module requires input datasets specifying land surface characteristics, such as land cover, vegetation parameters and soil texture. The Global Land Cover map for the year 2000 (GLC2000), developed by the Joint Research Centre of the European Commission (Bartholomé and Belward, 2005), is used to determine vegetation parameters such as Leaf Area Index (LAI) and root depth. Soil texture is derived from the Food and Agriculture Organization of the United Nations Digital Soil Map of the World (FAO, 1998).

The COSMO-CLM model uses a rotated spherical coordinate system to define the horizontal model grid, while the vertical grid is defined by a terrain following pressure-based hybrid coordinate system. In all simulations, 40 vertical levels are employed with a grid spacing of $25 \mathrm{~m}$ near the surface, increasing to $1 \mathrm{~km}$ near the upper model boundary, located at $25 \mathrm{~km}$ altitude.

\subsection{Experiment setup}

In order to assess the current UHI of Brussels and to evaluate the performance of UrbClim, the model is applied to simulate a 10-year reference period (2000-2009) for the wider urban agglomeration of Brussels (the ERA-INT simulation), directly driven with meteorological data from the ERA-Interim reanalysis of the European Centre for Medium-range Weather Forecasting (ECMWF), as was the setup in previous validation experiments (De Ridder et al., 2015). The domain is configured with $121 \times 121$ grid cells in the horizontal direction, using a spatial resolution of $250 \mathrm{~m}$. Fig. 1 shows the extent of the UrbClim model domain, the land use in the domain and the location of 3 measurement stations, which are used for model validation. In the vertical direction, 20 levels are specified, with the first level $10 \mathrm{~m}$ above the displacement height, the resolution smoothly decreasing upward to $250 \mathrm{~m}$ at the model top located at $3 \mathrm{~km}$ height. This vertical discretisation closely matches that of the ECMWF host model.

To assess the evolution of Brussels' UHI under plausible future climate conditions, results from the global climate model EC-Earth (Hazeleger et al., 2010; Hazeleger et al., 2012) are dynamically downscaled with COSMO-CLM and UrbClim. The outer COSMO-CLM model domain has a grid spacing of $25 \mathrm{~km}$ and a domain size of $100 \times 100$ grid points. Within this domain, a smaller domain with a resolution of $7 \mathrm{~km}$ is nested covering $150 \times 150$ grid points. The smallest domain for this study has a horizontal resolution of $3 \mathrm{~km}$ and covers $200 \times 200$ grid points. This large amount of grid cells is needed as the

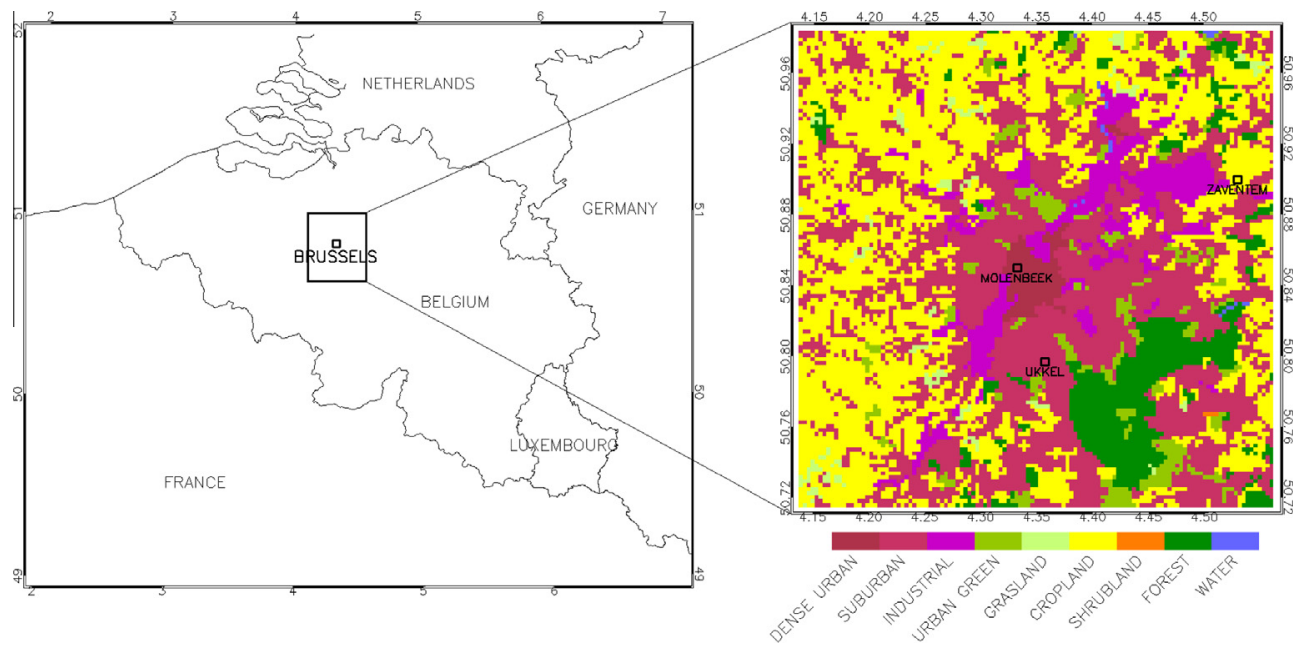

Fig. 1. Extent of the $3 \mathrm{~km}$ COSMO-CLM model domain and the $250 \mathrm{~m}$ UrbClim model domain centred around Brussels (left). The land use in the domain and the location of the observational stations are shown in the panel on the right. 
convective parameterization of COSMO-CLM is turned off at this high resolution, and the model needs a large enough model domain to develop the resolved convection. The COSMO-CLM simulations are performed using one-way grid nesting. The COSMO-CLM setup that is used in this study is in more detail described and evaluated by Brisson et al. (2015).

The model chain described above is applied to simulate a 10-year reference period (2000-2009) (the REF simulation), driven with meteorological data from the base run of the global climate model EC-Earth. Secondly, a 10-year period in the future (2060-2069) is simulated, driven with EC-Earth model results for the Intergovernmental Panel on Climate Change (IPCC) RCP4.5 and RCP8.5 (Van Vuuren et al., 2011), two of the RCPs used in the climate simulations of the Coupled Model Intercomparison Project (CMIP5).

In order to assess the capacity of the COSMO-CLM driven reference (REF) simulation to reproduce the current UHI conditions, a comparison is made of the 10-year (2000-2009) statistics of the UHI of Brussels in Section 3.3. Since the EC-Earth-COSMO-CLM simulations target a climate realisation and not an actual reconstruction of the weather patterns, it is not possible to validate the modelled time series directly by comparison to observations. However, if we remove the year-to-year variability by taking the 10-year statistics for the present day period, the values should be comparable to the ERA-Interim driven simulations.

This study focusses on the summer months (June, July and August), since this is the period when the highest temperature events and strongest UHIs occur over Belgium (Van Weverberg et al., 2008). Each year, the simulations with UrbClim are initialized on 1 April at 0000 LT, resulting in a two-month spin-up before the start of the analysis on 1 June each summer, in order to ensure model equilibrium between external forcing and internal dynamics, especially in terms of soil variables. Initial soil temperature and soil moisture data are taken from the ERA-Interim reanalysis or the COSMO-CLM model, respectively.

\section{Results and discussion}

\subsection{Model evaluation}

The UrbClim model has already been successfully validated regarding its energy fluxes, $2 \mathrm{~m}$ air temperatures and urbanrural temperature differences for the cities of Antwerp, Ghent (Belgium) and Toulouse (France) in Lauwaet et al. (2015) and De Ridder et al. (2015). Also the land surface temperatures in the UrbClim land surface scheme, the main focus of the present study, have already been validated in the past with satellite data. In De Ridder (2006), the urban parameterization is tested for the city of Paris, and the simulated land surface temperatures compare favourably to observed values obtained from thermal infrared satellite imagery. Afterwards, the land surface scheme was coupled to a mesoscale atmospheric model and applied to both Paris and the German Ruhr area, again yielding good comparisons between simulated and observed land surface temperatures from thermal infrared satellite imagery (De Ridder et al., 2008, 2012).

Regarding the Brussels domain used in this study, we were able to obtain hourly $2 \mathrm{~m}$ temperature measurement data for a location inside the densely built-up city centre (Molenbeek, 50.850N, 4.333E) from the Brussels Institute of Environment (IBGE-BIM). Unfortunately, only data for the summer period of 2008 are available. Furthermore, data from a semi-urban station (Ukkel, 50.797N, 4.357E) and a rural station (Zaventem, 50.900N 4.531E) were gathered from the database of the National Climatic Data Centre (NCDC). These data are available for the full 10-year period (2000-2009). The error statistics of the UrbClim model for hourly $2 \mathrm{~m}$ air temperatures at all three locations during the summer (JJA) of 2008 are shown in Table 1 . Clearly, the overall performance of the model is good, with a bias below $1{ }^{\circ} \mathrm{C}$, root mean square errors just above $1{ }^{\circ} \mathrm{C}$, and correlation coefficients of 0.94 .

However, even more important is the model's ability to reproduce observed urban-rural temperature differences. Clearly, this quantity is much harder to correctly reproduce, as it arises as a rather small difference of two values exhibiting a comparatively large diurnal amplitude. Nevertheless, the time series and error statistics show a fair agreement between the simulated and observed temperature differences during the summer of 2008 , with a small positive bias of less than $0.5^{\circ} \mathrm{C}$, a root mean square error in the order of $1^{\circ} \mathrm{C}$ and a correlation coefficient over 0.6 (Fig. 2).

Since our analysis of the UHI of Brussels will focus on the night time UHI at 0000 LT, we want to assess this value for a long time period. Only data for the stations of Ukkel and Zaventem are available for the full 2000-2009 period, so the temperature difference between both stations is plotted in Fig. 3. The UHI signal between these stations is rather small, which makes it harder to reproduce. Although there is a considerable spread in the results, the model is able to reproduce the

Table 1

Error statistics for the simulated urban (Molenbeek), semi-urban (Ukkel) and rural (Zaventem) hourly $2 \mathrm{~m}$ air temperatures for the period June-August 2008. The quantities given are the bias (model-observations), root mean square error (RMSE), and correlation coefficient (CORR).

\begin{tabular}{llll}
\hline & BIAS $\left({ }^{\circ} \mathrm{C}\right)$ & RMSE $\left({ }^{\circ} \mathrm{C}\right)$ & CORR \\
\hline Molenbeek & 0.76 & 1.32 & 0.94 \\
Ukkel & 0.36 & 1.34 & 0.94 \\
Zaventem & 0.35 & 1.40 & 0.93 \\
\hline
\end{tabular}



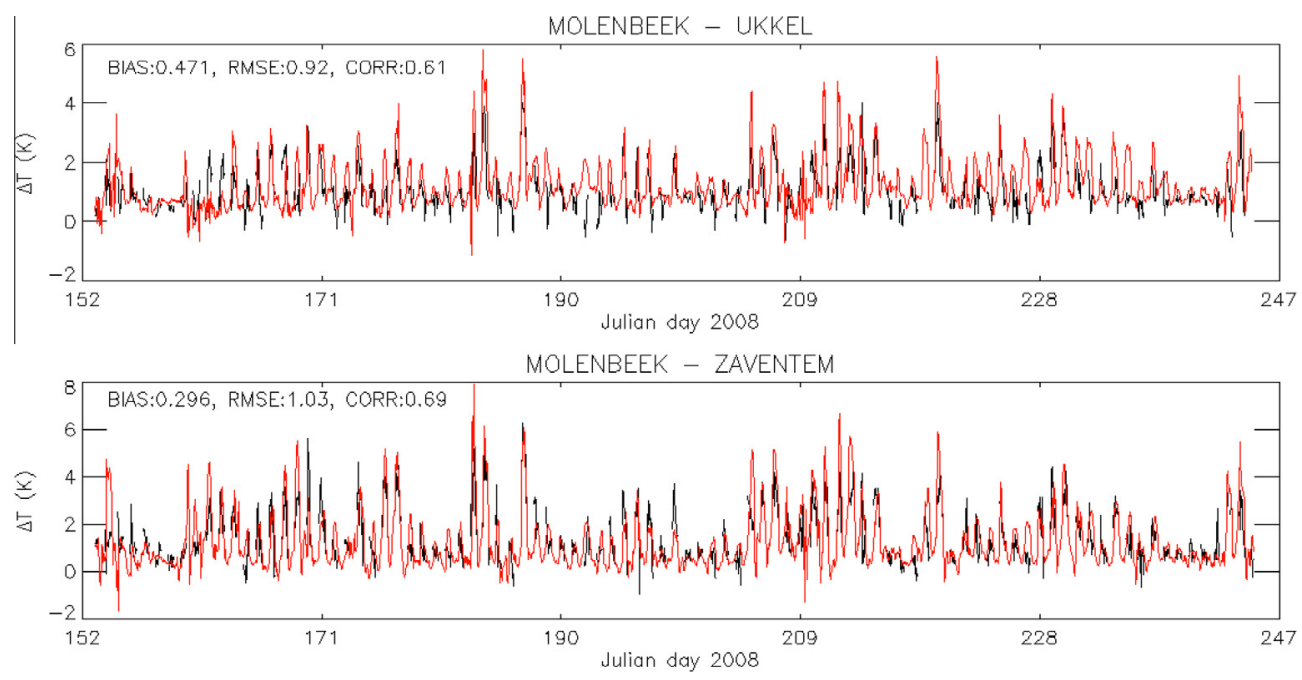

Fig. 2. Time series of $2 \mathrm{~m}$ air temperature differences $(\Delta T)$ between the urban station and the two other stations for the period June-August 2008 . Observations are in black, model results in red. The quantities given are the bias, root mean square error (RMSE), and correlation coefficient (CORR). (For interpretation of the references to colour in this figure legend, the reader is referred to the web version of this article.)

10-year series almost without a mean bias, a root mean square error around $1{ }^{\circ} \mathrm{C}$ and a correlation coefficient of 0.53 . Overall, the UrbClim model performs satisfactorily and seems well suited to address the research questions in this study.

\subsection{Present climate UHI}

In this study, we focus on the night time UHI of Brussels at $0000 \mathrm{LT}$, since this is the time of day that the UHI is the strongest (both in the model and in the observations) and has the biggest potential impact on human health, because the warmer urban night-time temperatures limit the recuperation of city inhabitants from heat stress during daytime (Changnon et al., 1996). The UHI intensity is calculated as the difference between the 90th and 10th percentile of the temperatures of the entire UrbClim domain at $0000 \mathrm{LT}$, in order to obtain a relatively general value of UHI intensity for the whole of Brussels, without taking only the extreme locations into account. Calculated this way, the mean UHI intensity of Brussels over all summer periods during 2000-2009 from the ERA-Interim driven simulations amounts to $3.15^{\circ} \mathrm{C}$. This is slightly higher than the value of $2.54{ }^{\circ} \mathrm{C}$, reported by Hamdi et al. (2013) for the period 1961-1990 in their modelling study. However, their value is based on the minimum temperatures during the night, which occur just before morning when the UHI effect is already over

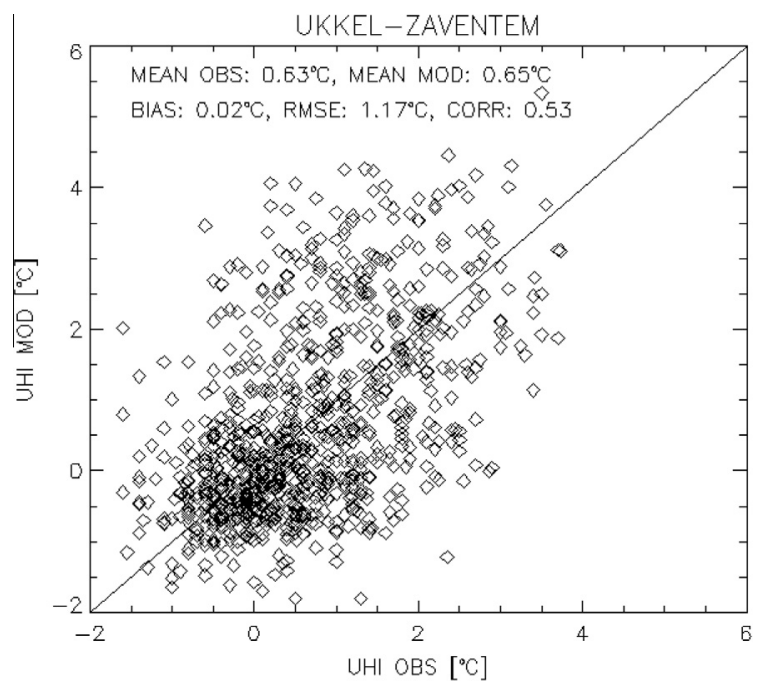

Fig. 3. Comparison of modelled and observed $2 \mathrm{~m}$ air temperature differences at midnight (0000 LT) between the stations of Ukkel and Zaventem for the summer periods (June-August) of 2000-2009. 

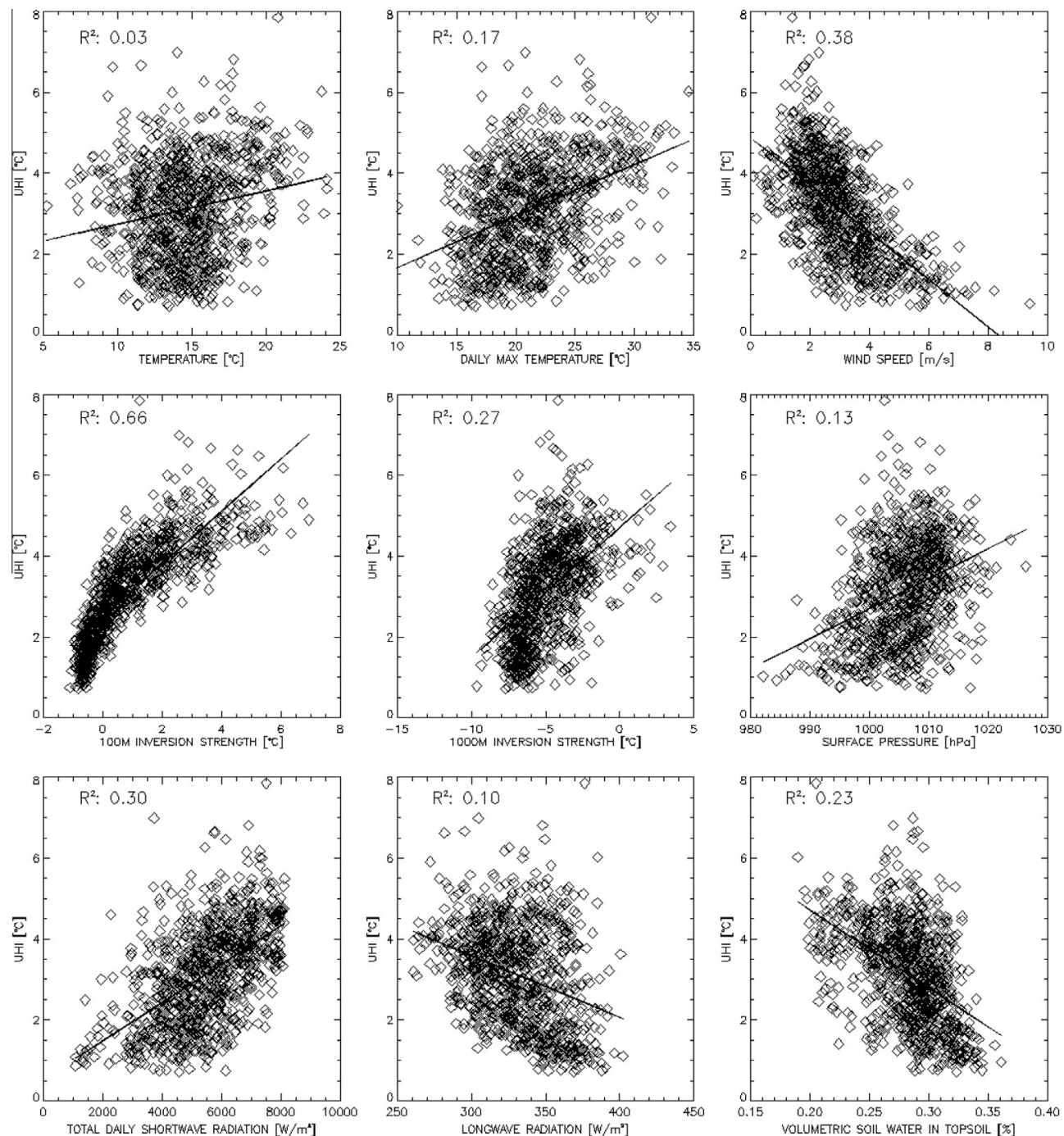

Fig. 4. Relation between the simulated UHI intensities in Brussels at midnight (0000 LT) and different meteorological variables from ERA-Interim for the summer periods (June-August) of 2000-2009.

its maximum. The difference also can partly be attributed to the higher model resolution in this study, which lead to more homogeneous land cover and vegetation properties of the model grid cells, resulting in a more realistic micrometeorology replication and more extreme temperature values.

Fig. 4 shows the relationships between the daily night-time UHI values from the ERA-Interim driven simulations and several meteorological parameters that are expected to play a role in the formation and intensity of the UHI. As was the case in several observational studies (e.g. Giannaros and Melas, 2012; Kim and Baik, 2005), UHI intensity is found to be negatively correlated to the wind speed. Also positive correlations with incoming shortwave radiation (a measure for cloud cover), surface pressure and daily maximum temperatures are found, as well as negative correlations with soil water (a measure for recent precipitation) and incoming longwave radiation. By far the strongest correlation (0.66) is found for the inversion strength in the lowest $100 \mathrm{~m}$ of the atmosphere. When taking a larger part of the temperature profile into account $(1000 \mathrm{~m})$, the correlation decreases strongly to 0.27 . A similar correlation with surface inversion strength is reported by Gedzelman et al. (2003) for the city of New York, although they limited their data to only cases when the inversion height was less than $300 \mathrm{~m}$ to reach equally high correlation values (0.69). In New York, strong sea breezes were found to be destroying the nocturnal inversion during large parts of the year, something that is not happening in an inland city such as Brussels.

In Fig. 5, the influence of the wind direction on the strength of the UHI is explored. Clearly, wind direction has a profound influence on the magnitude of Brussels' UHI. In cases where there is an easterly wind component, which happens only $25 \%$ of the time, the UHI reaches mean values around $4{ }^{\circ} \mathrm{C}$. This corresponds in Belgium with an advection of land born air masses, 

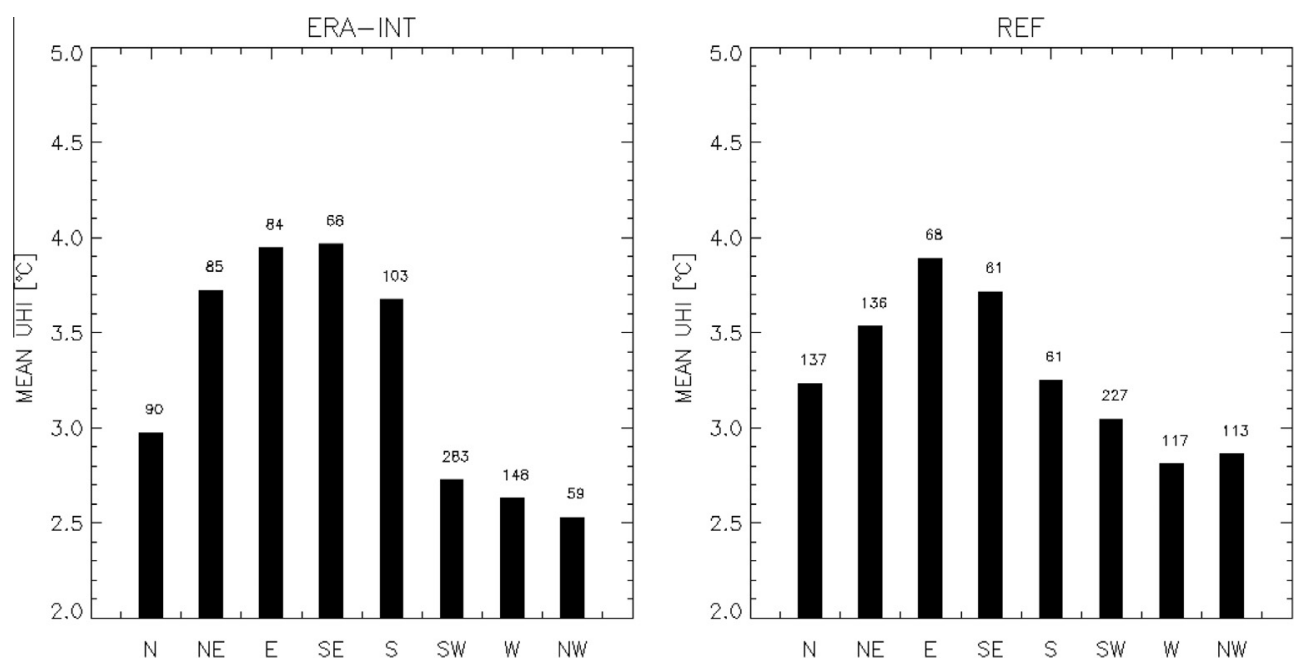

Fig. 5. Mean UHI intensities in Brussels at midnight (0000 LT) for every wind direction for respectively the ERA-INT and REF experiments. The numbers on top of the stacks indicate the amount of cases the stack value is based on.

resulting in mainly dry and cloud free conditions with light winds during which a strong nocturnal inversion can form. In case of westerly wind conditions on the other hand, which are dominant in Belgium, the smallest mean UHI intensities are produced. When the wind has a westerly component, it comes from over the North Sea, bringing moist air, clouds and rainfall inland, which leads to conditions least favourable for the development of the UHI.

\subsection{Comparison between ERA-INT and REF}

Overall, the mean UHI intensity of the REF simulation is $3.22^{\circ} \mathrm{C}$, slightly higher than the value of the ERA-Interim driven simulation. The right-hand panel of Fig. 5 shows that the wind dependency of the UHI is reproduced although the difference between the easterly and westerly components is smaller. Furthermore, the wind pattern is slightly different in the REF simulation: there is an increase (+60\%) in the amount of days with northerly winds, whereas there is a decrease $(-25 \%)$ in days with winds coming from the South, Southwest and West. When exploring the differences between both simulations, it is found that the amount of cloud cover is overestimated by COSMO-CLM, which leads to fewer formations of a very strong UHI, especially on days with easterly winds. On the other hand, the higher resolution and more detailed turbulence calculation of COSMO-CLM results in generally stronger inversions during the night, which explains the overall higher UHI values.

All in all, these differences have little effect on the resulting distribution of the UHI intensities over the 2000-2009 period (Fig. 6). There are fewer very weak and very strong UHI intensities in the REF simulation, and there is a small shift towards higher intensities, but overall the histograms are comparable. We can thus conclude that the REF simulation reproduces the current UHI conditions satisfactorily, making it an effective base case to compare the future climate simulations against.

\subsection{Future climate UHI}

The impact of two plausible trajectories for future climate conditions, RCPs 4.5 and 8.5, on the UHI of Brussels and related meteorological parameters is shown in Table 2. The RCP4.5 and RCP8.5 simulations span the period 2060-2069. Clearly, the $\mathrm{UHI}$ of Brussels is not increasing in response to greenhouse-gas induced climate change, with 10-year mean values changing not significantly (at a <1\% level) in RCP4.5 and even decreasing slightly in RCP8.5. Interestingly, most related meteorological parameters do show changes that should benefit UHI formation (temperature, maximum temperature and wind speed) or do not change significantly (inversion strengths, rainfall and soil moisture). Only the radiation parameters show significant changes that have a negative effect on UHI formation. Whereas the changes in incoming solar radiation are not in line with the changes in the UHI, the slightly increasing incoming longwave radiation is found to play an important role.

The increase in incoming longwave radiation in RCP8.5 is caused by higher air temperature and humidity values, since no significant changes in the night-time cloudiness were found. Indeed, when we use the overall temperature and humidity values from the reference and RCP8.5 simulations, we can calculate the expected changes in downward longwave radiation by applying the equation of Brutsaert (1975), which results in a difference of $11.6 \mathrm{~W} \mathrm{~m}^{-2}$ between both simulations (314.5 and $326.1 \mathrm{~W} \mathrm{~m}^{-2}$ respectively) that is clearly in line with the values in Table 2.

To explain the slight reduction of UHI intensities in the future scenarios, we have performed an additional analysis on the role of the extra longwave radiation. It has been reported before by Oleson et al. (2011) that increased incoming longwave radiation warms rural areas more than urban areas at night due to the different storage capacities of the urban and rural 


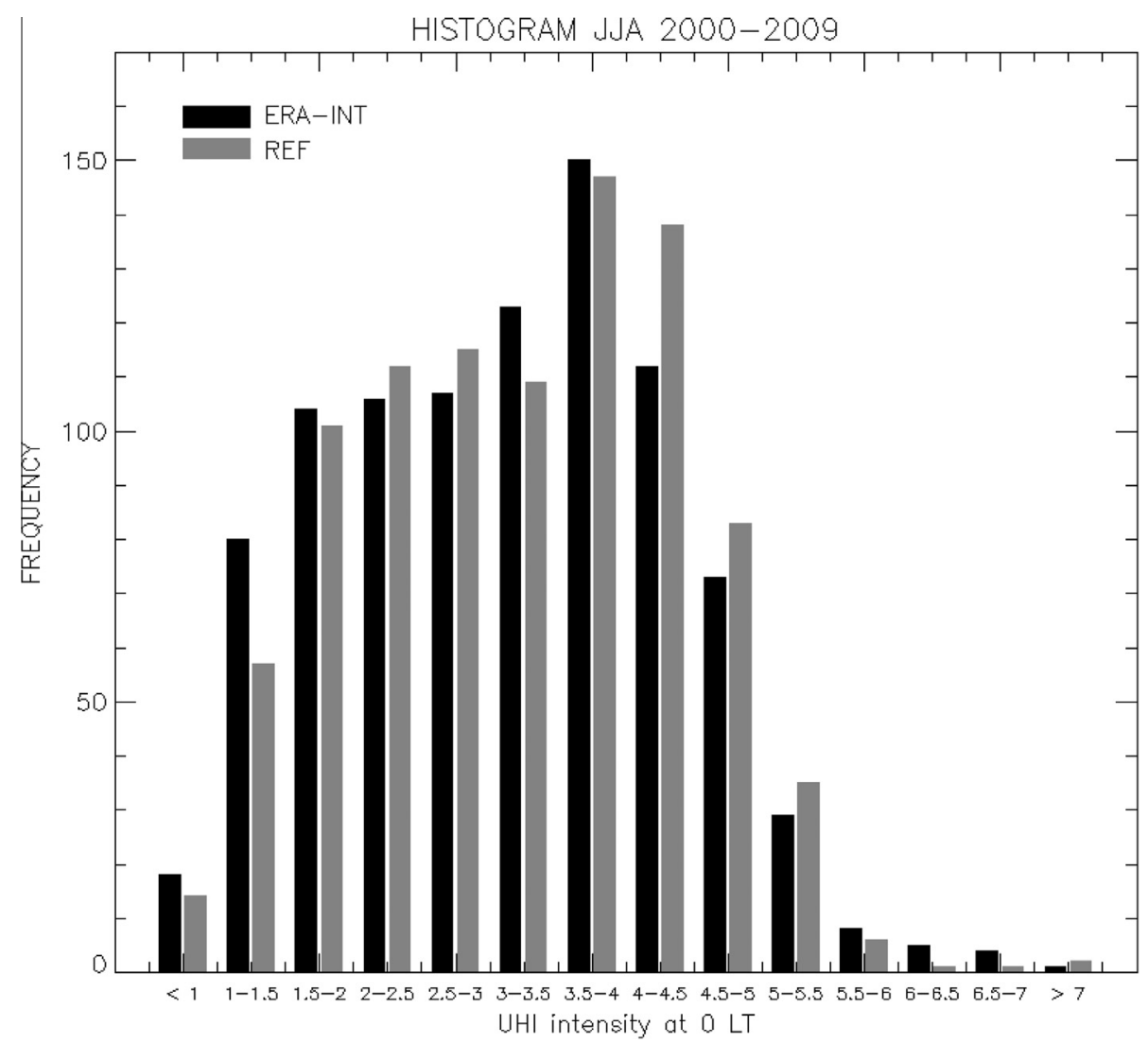

Fig. 6. Histogram of UHI intensities in Brussels for both the ERA-INT and REF experiments over all summer periods (June-August) during 2000-2009.

Table 2

Overview of the 10-year mean values (REF: 2000-2009; RCP4.5 and RCP8.5: 2060-2069) over all summer periods (JuneAugust) for the UHI of Brussels and related meteorological variables for the reference and future climate simulations. Significant differences from the REF simulation (at $a<1 \%$ level) are indicated in bold.

\begin{tabular}{llll}
\hline & REF & RCP4.5 & RCP8.5 \\
\hline UHI $\left({ }^{\circ} \mathrm{C}\right)$ & 3.22 & 3.20 & $\mathbf{3 . 0 8}$ \\
Temperature $\left({ }^{\circ} \mathrm{C}\right)$ & 17.4 & $\mathbf{1 8 . 3}$ & $\mathbf{1 8 . 9}$ \\
Daily max temperature $\left({ }^{\circ} \mathrm{C}\right)$ & 21.6 & $\mathbf{2 2 . 5}$ & $\mathbf{2 3 . 2}$ \\
$100 \mathrm{~m}$ inversion strength $\left({ }^{\circ} \mathrm{C}\right)$ & 0.01 & -0.07 & 0.08 \\
Wind speed $\left(\mathrm{m} \mathrm{s}^{-1}\right)$ & 2.55 & $\mathbf{2 . 2 1}$ & $\mathbf{2 . 1 7}$ \\
Rainfall per summer $(\mathrm{mm})$ & 180 & 181 & 178 \\
Volumetric water content topsoil $(\%)$ & 0.28 & 0.29 & 0.28 \\
Mean daily shortwave radiation $\left(\mathrm{W} \mathrm{m}^{-2}\right)$ & 220 & $\mathbf{2 0 1}$ & $\mathbf{2 1 0}$ \\
Longwave radiation $\left(\mathrm{W} \mathrm{m}^{-2}\right)$ & 330 & 333 & $\mathbf{3 4 2}$ \\
\hline
\end{tabular}

areas. The same effect is found to play a role in the offline simulations of Hamdi et al. (2013), although they don't see the effect in their online simulations. To isolate the impact of added longwave radiation, a case study is set up for the night from the 4th to the 5th of July 2008, during which a strong UHI formed (Day 187 in Fig. 2). These two days are simulated again, driven with ERA-Interim data, but with an addition of $12 \mathrm{~W} \mathrm{~m}^{-2}$ to the incoming longwave radiation in the input data, the mean difference between the RCP8.5 and REF scenario (Table 2).

Fig. 7 presents the resulting potential temperature profiles for a rural and urban location at $0000 \mathrm{LT}$. The extra longwave radiation heats the surface in both the urban and rural locations, resulting in an additional sensible heat flux that warms the overlying air. In the urban location, the temperature profile is more or less neutral and the additional sensible heat flux has a small but noticeable effect, spread over the lowest $400 \mathrm{~m}$ of the profile, only slightly warming the part of the profile closest to the surface. In the rural location, a strong inversion has formed and here the sensible heat flux induced by the extra longwave radiation can only affect the lowest few metres of the profile, so the effect on the $2 \mathrm{~m}$ temperature $\left(+0.35^{\circ} \mathrm{C}\right)$ is much higher than in the urban location $\left(+0.05^{\circ} \mathrm{C}\right)$. The resulting UHI intensity is thus reduced by $0.3^{\circ} \mathrm{C}$. This mechanism can 

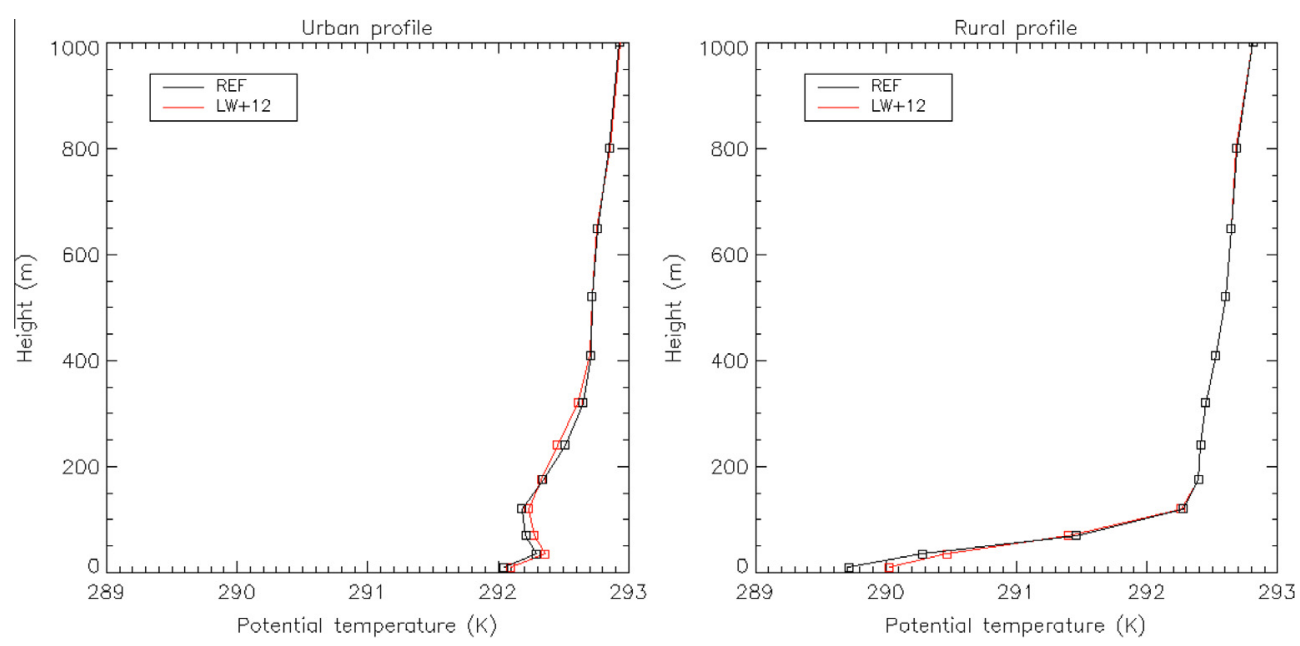

Fig. 7. Potential temperature profiles at 0000 LT on 5 July 2008 at an urban and rural location for both the reference simulation (REF) and the simulation with $12 \mathrm{~W} \mathrm{~m}^{-2}$ added longwave radiation ( $\left.\mathrm{LW}+12\right)$. The urban and rural locations are defined as the location of respectively the 90 th and 10 th percentile of the $2 \mathrm{~m}$ air temperature map at $0000 \mathrm{LT}$.
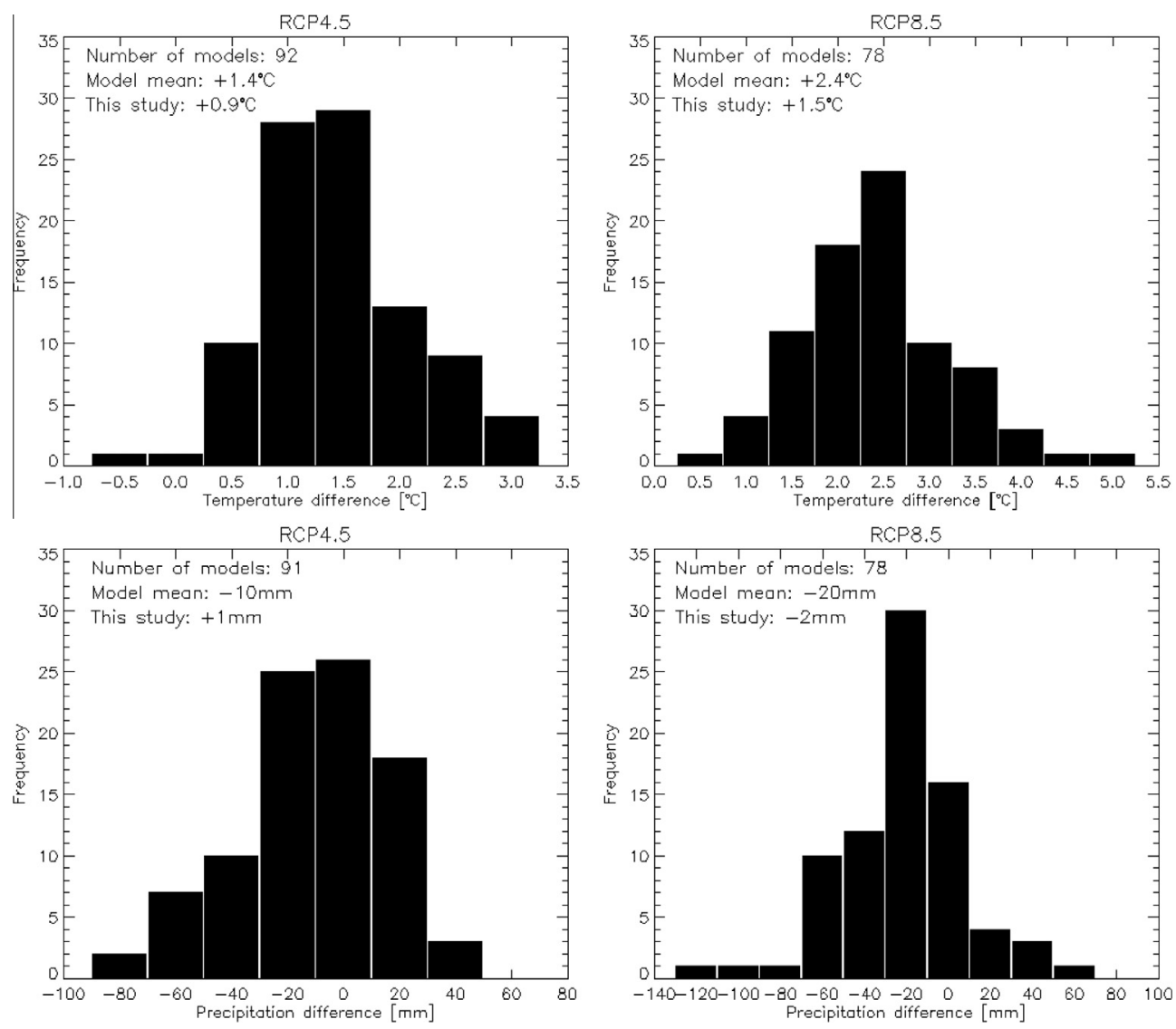

Fig. 8. Histograms of the temperature and precipitation differences in Brussels for the summer months (June-August) between the periods 2000-2009 and 2060-2069 from all available members of the CMIP5 model ensemble.

explain why we see a slight decrease in the overall UHI intensities in the RCP scenarios whereas other meteorological variables support an at least equally strong UHI.

Overall, these results are in line with previous reported research on this topic. Fischer et al. (2012) and Oleson (2012) studied the effect of several greenhouse gas scenarios on UHI intensities by the end of the century on a global scale, and 

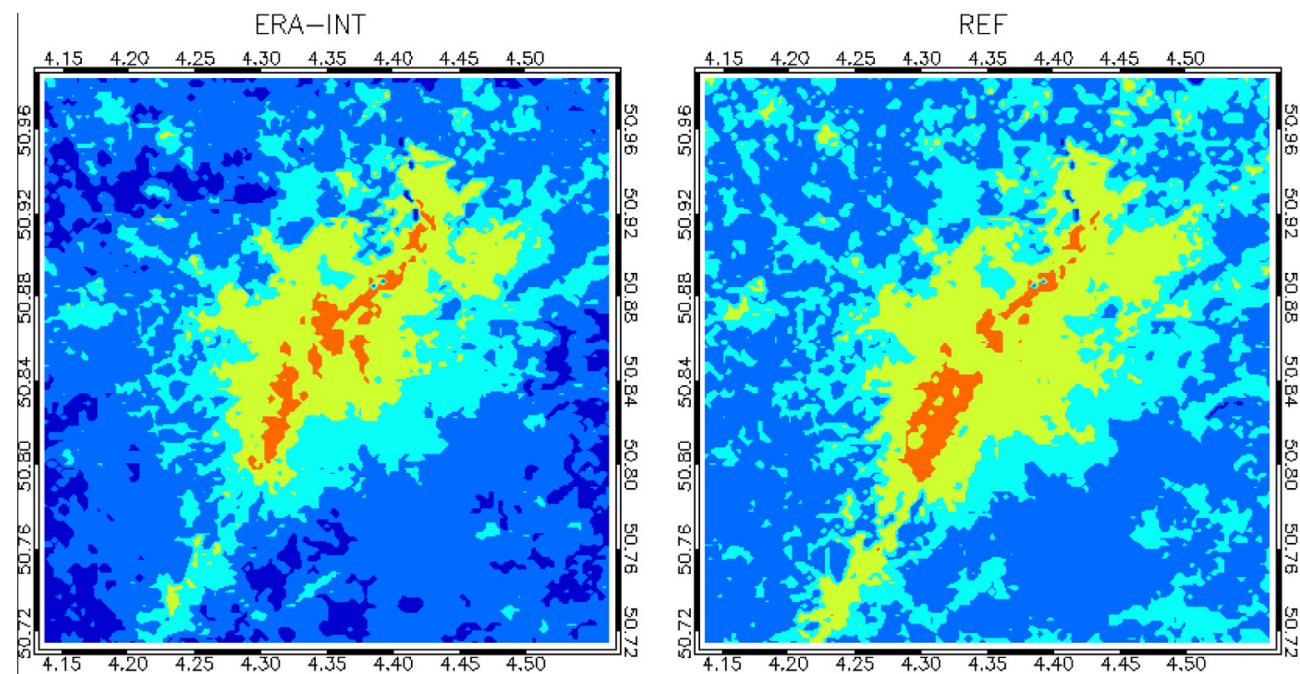

RCP4.5

RCP8.5

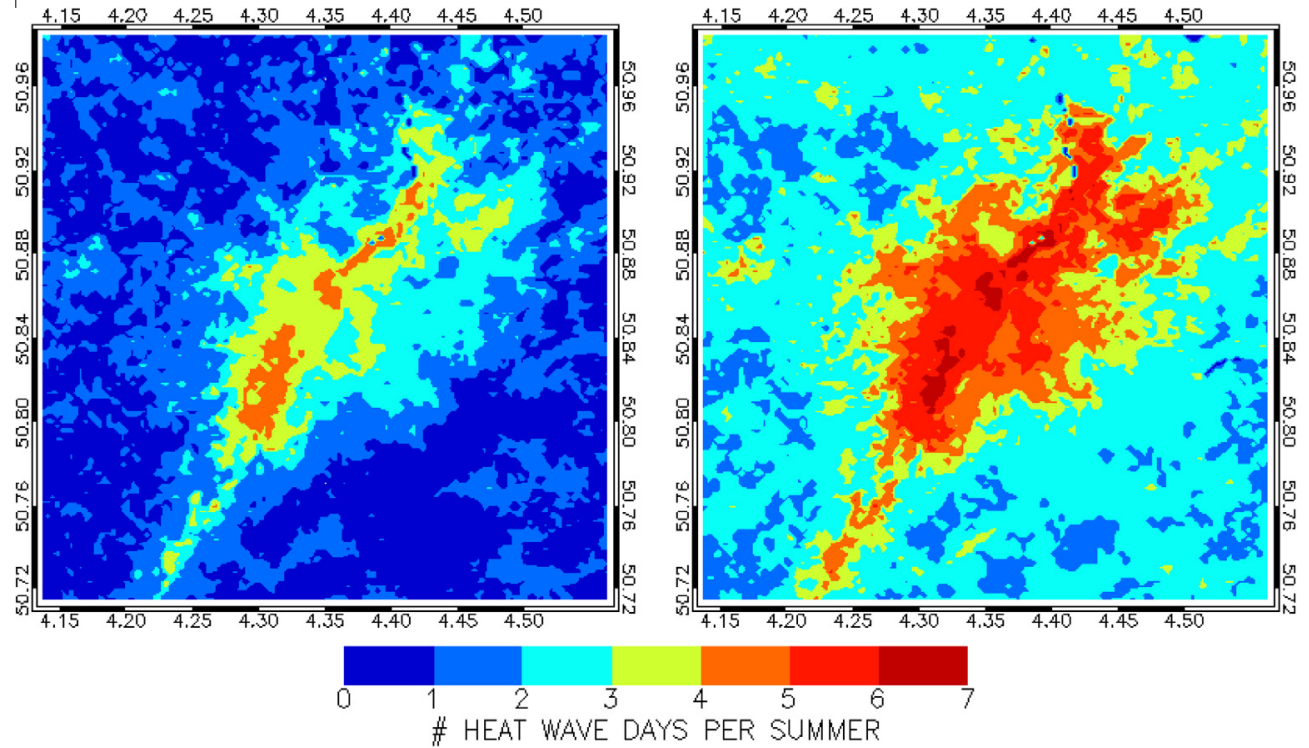

Fig. 9. Maps of the number of Heat Wave Days per summer (June-August) for all 10-year simulations.

found little changes in the UHI values as the urban and rural areas showed a similar warming trend. McCarthy et al. (2012) also obtained rather constant, although not static, UHI values for the cities in the United Kingdom under climate change conditions in their regional climate model simulations. Applying a much higher spatial resolution, Lemonsu et al. (2013) and Hamdi et al. (2013) reported a relatively strong decrease in the night-time UHI intensities of Paris $\left(-1{ }^{\circ} \mathrm{C}\right)$ and Brussels $\left(-0.36{ }^{\circ} \mathrm{C}\right)$, respectively. They could attribute these changes to a large reduction of the summer rainfall amounts by the end of the century in their simulations, strongly diminishing the evaporation from vegetation and soils in the rural areas, which gives rise to higher rural temperatures and hence a smaller UHI. In our simulations, this is clearly not the case since in both RCP scenarios the rainfall amounts remain at present-day levels.

To frame the results of this study even more into the general climate change context, an analysis is performed regarding the projected climate change signal for Brussels, using all available members from the CMIP5 multi-model ensemble (Taylor et al., 2012). Fig. 8 shows histograms of the projected summer temperature and precipitation changes between 2005 and 2065 for the RCP4.5 and RCP8.5 scenario, comparing them to the values of our simulations. There is a considerable spread in the results of the multi-model ensemble, although the main trends are clearly visible: a warming around $1.5^{\circ} \mathrm{C}$ and more or less constant precipitation values for RCP4.5, and a strong warming around $2.5^{\circ} \mathrm{C}$ with slightly less summer precipitation for RCP8.5. Our results are close to the multi-model mean values, albeit a little colder and wetter. The projections of this study are thus in line with the global reference dataset. 


\subsection{Effect on heat wave days}

Although the magnitude of Brussels' UHI is not expected to change a lot in the (near) future, the presence of the urban heat island does have an impact on extreme temperatures, especially during the night, which are expected to occur more frequently in the future. This has important consequences for human health, since consecutive hot nights during which people cannot recuperate from extreme daytime temperatures may be most detrimental to the health of city inhabitants (Karl and Knight, 1997). With regard to human health and exposure mapping, the high spatial resolution of UrbClim provides much added value. A resolution of $250 \mathrm{~m}$ is considerably finer than what is customarily used in climate modelling studies over cities, which generally employ resolutions of around $1 \mathrm{~km}$ or coarser. In this context, it should be noted that Sobrino et al. (2012), based on the analysis of aerial thermal-infrared imagery over Madrid, concluded that a spatial resolution of the order of a few hundred metres resolves the detail at the city neighbourhood scale much better than a $1 \mathrm{~km}$ resolution. De Ridder et al. (2014) found that exposure, in their case to $\mathrm{NO}_{2}$ concentrations over Brussels, decreased by $38 \%$ when degrading the resolution of their model several times by a factor of 4 .

In the literature, a large number of definitions for extreme heat events exists, which all share some common properties (Smith et al., 2013). Since health effects become especially severe during prolonged periods of hot weather, most definitions consider multiple consecutive days of extreme weather. Mostly, the definitions also deal with minimum and maximum temperatures, since lack of cooling during the night is an important factor in health effects related to heat stress. Finally, definitions generally make use of statistically determined thresholds. In this study, we opted to apply the definition from the Federal Agency for Public Health in Belgium, which defines a Heat Wave Day (HWD) as a day that both the 3-day moving average minimal and maximal temperatures exceed a threshold value, listed as $18.2{ }^{\circ} \mathrm{C}$ and $29.6{ }^{\circ} \mathrm{C}$, respectively. These values correspond to the 98th percentiles of the summer (JJA) temperatures in the observational station of Ukkel, the national reference station.

Fig. 9 shows the annual amount of HWDs for all 10-year simulations in this study. Clearly, in present day conditions, due to the UHI effect the city inhabitants experience 2-3 times as many Heat Wave Days as people living in the countryside. For the RCP4.5 simulation, the map looks fairly similar to the present day maps, as the changes in the temperatures apparently are too weak to trigger more extreme heat events, partly a consequence of using rigid thresholds. For the RCP8.5 simulation, where the temperature changes are larger, there is a strong increase in the number of HWDs in the city centre. Also the area where more than 4 HWDs per year occur, the maximum amount for present day conditions, is expanding by a factor around 5. In the rural areas, the increase is limited to 1-2 HWDs. Thus, although the UHI effect itself is slightly decreasing in this scenario, the future risk of extreme heat events in the city area is compounded by its presence. Similar results are found by McCarthy et al. (2012), Oleson (2012) and Hamdi et al. (2013), although in their studies the impact of the UHI on extreme events is even larger, as they investigated climate scenarios at the end of the 21st century, where the temperature changes are more drastic than in our scenarios.

\section{Conclusions}

In this paper, the current urban heat island of Brussels and the meteorological parameters that play a role in its formation were assessed with the urban boundary layer climate model UrbClim, at an unprecedented horizontal resolution of $250 \mathrm{~m}$. Furthermore, the evolution of the UHI for two plausible trajectories for future climate conditions (RCP4.5 and RCP8.5) were investigated. The UrbClim model takes into account advection and feedback processes between the urban surface and the atmosphere, that cannot be included in studies with offline surface schemes. For the experiments considered here, UrbClim was driven with meteorological input from either the ERA-Interim reanalysis of ECMWF or the regional climate model COSMO-CLM, for which large-scale boundary conditions were obtained from the global climate model EC-Earth.

The model was able to reproduce the observed differences in time series of air temperatures from different stations, with very small positive biases, root mean square errors around $1{ }^{\circ} \mathrm{C}$ and correlation coefficients up to 0.7 . Overall, the mean night-time (0000 LT) UHI of Brussels amounted to $3.15^{\circ} \mathrm{C}$ for the $2000-2009$ reference period. UHI intensity was found to be most strongly correlated to the inversion strength in the lowest $100 \mathrm{~m}$ of the atmosphere $\left(R^{2}\right.$ of 0.66$)$. Furthermore, strong positive correlations to incoming shortwave radiation (a measure for cloud cover), surface pressure and daily maximum temperatures were found, as well as negative correlations with wind speeds, soil water (a measure for recent precipitation) and incoming longwave radiation. A deeper analysis revealed a that easterly winds lead to stronger UHIs.

The results for the future scenarios showed that the UHI of Brussels is not expected to increase, as the 10-year mean values did not change or decreased slightly for the applied scenarios, even though most meteorological parameters showed changes that should benefit UHI formation. An additional case study in which the role of increased incoming longwave radiation was investigated, demonstrated its diversifying effect on rural and urban temperature profiles, decreasing the UHI effect. This mechanism could explain the previously mentioned decreasing UHI values in the future simulations, and is supported by related research studies. An analysis of extreme heat events, defined in this study as Heat Wave Days, confirmed the findings of several previous papers on this topic that even though the UHI itself is not increasing, in the urban region the risk of extreme heat events, which are expected to increase in response to climate change, is compounded by its presence.

Note that our simulations do not account for potential future urban growth, an effect that typically increases the urbanrural contrasts. Also, we use the results of only two RCP scenarios, calculated with one global climate model, coupled to one 
regional climate model, so we cannot estimate the resulting uncertainty with respect to alternative climate change scenarios or global/regional climate models. Given these limitations and substantial uncertainties, the results presented here are not suited for local risk assessment but should rather provide a coherent picture of potential heat stress changes in the city area due to increasing greenhouse-gas emissions and resulting warming. Our results emphasize the need to focus on the unique aspects of urban climate in order to design well-informed adaptation strategies in urban areas.

\section{Acknowledgements}

This research has been performed in the framework of the Modelling Atmospheric Composition and Climate for the Belgian Territory (MACCBET) project, funded by the program Science for a Sustainable Development (SSD) of the Belgian Science Policy Office (BELSPO) under contract number SD/CS/04A. Furthermore, the work described in this paper has received funding from the European Community's 7th Framework Programme under Grant Agreements Nos. 308497 (RAMSES) and 308299 (NACLIM). For the COSMO-CLM model simulations, we used the Flemish Supercomputer Center, funded by the Hercules Foundation and the EWI Department of the Flemish Government.

\section{Appendix A. Longwave radiation feedback}

The UrbClim model specifies downwelling radiation from output fields generated by the host model, which are interpolated to the centre of the UrbClim domain, and applied uniformly over the latter. By doing so, we ignore the spatial variability that occurs in the downwelling longwave radiation, which is itself a consequence of the horizontal variability of the vertical temperature profiles. In particular, air temperature being more elevated over cities, especially at night, one would expect a higher downwelling longwave radiation at the surface.

To assess the magnitude of this effect, we analysed downwelling longwave radiation as a function of near surface air temperature, using a simple but widely used parameterization (see, e.g., Sedlar and Hock, 2009), given by

$$
R_{l} \cong \varepsilon_{a} \sigma T_{a}^{4},
$$

with $R_{l}$ the downwelling longwave radiation at the surface, $\varepsilon_{a}$ the atmospheric emissivity, $\sigma$ the Stefan Boltzmann constant, and $T_{a}$ the 2-m air temperature.

The above expression can be applied separately for urban and rural conditions. Assuming that atmospheric emissivity (which is generally parameterized as a function of humidity) is not too different between the urban and nearby rural location, we obtain

$$
\begin{aligned}
& R_{l u} \cong \varepsilon_{a} \sigma T_{a u}^{4} \\
& R_{l r} \cong \varepsilon_{a} \sigma T_{a r}^{4},
\end{aligned}
$$

the subscripts ' $u$ ' and ' $r$ ' denoting urban and rural values, respectively.

Now, putting $T_{a u}=T_{a r}+\Delta T$, and developing the difference in urban and rural downwelling longwave radiation $R_{l u}-R_{l r}$ in a Taylor series to first order in $\Delta T$, one finds

$$
R_{l u} \cong\left(1+\frac{4 \Delta T}{T_{a r}}\right) R_{l r},
$$

This means that for a given urban-rural air temperature increment $\Delta T$ (which in fact is the UHI intensity), taking the large-scale host model value for the downwelling longwave radiation (which presumably is representative of the rural rather than the urban value) induces an underestimation of the downwelling longwave radiation over the urban area by a factor of $4 \Delta T / T$ which, for representative values of $\Delta T$ and $T$, amounts to maximum $4 \%$ of the downwelling radiation.

Given that the latter typically has a value of a few hundred $\mathrm{W} \mathrm{m}^{-2}$, the resulting error on the urban downwelling longwave radiation is of the order of $10-15 \mathrm{~W} \mathrm{~m}^{-2}$. As demonstrated in the sensitivity analysis concerning the additional climate-change related downwelling longwave radiation (see Section 3.4), the impact of an extra longwave radiation input of this magnitude hardly affects the simulated near-surface temperature in the urban area.

\section{References}

Argüeso, D., Evans, J.P., Fita, L., Bormann, K.J., 2013. Temperature response to future urbanization and climate change. Clim. Dyn. http://dx.doi.org/10.1007/ s00382-013-1789-6.

Arnfield, A.J., 2003. Two decades of urban climate research: a review of turbulence, exchanges of energy and water, and the urban heat island. Int. J. Climatol. 23, 1-26. http://dx.doi.org/10.1002/joc.859.

Bartholomé, E., Belward, A.S., 2005. GLC2000: a new approach to global land cover mapping from Earth observation data. Int. J. Remote Sens. 26 (9), $1959-$ 1977.

Bornstein, R.D., 1968. Observations of the urban heat island effect in New York city. J. Appl. Meteorol. 7, 575-582.

Brisson, E., Demuzere, M., van Lipzig, N.P.M., 2015. A study on modelling strategies for performing convective permitting climate simulations using the COSMO-CLM over a mid-latitude coastal region. Met. Zeit., in press.

Brutsaert, W., 1975. On a derivable formula for long-wave radiation from clear skies. Water Resour. Res. 11 (5), 742-744.

Changnon, S.A., Kunkel, K.E., Reinke, B.C., 1996. Impacts and responses to the 1995 heat wave: a call to action. Bull. Am. Meteorol. Soc. 77, 1497-1506. 
Danielson, J.J., Gesch, D.B., 2011. Global multi-resolution terrain elevation data 2010 (GMTED2010). U.S. Geological Survey Open-File Report 2011-1073, $26 \mathrm{p}$.

De Ridder, K., 2006. Testing Brutsaert's temperature roughness parameterization for representing urban surfaces in atmospheric models. Geophys. Res. Lett. 33. http://dx.doi.org/10.1029/2006GL026572.

De Ridder, K., Schayes, G., 1997. The IAGL land surface model. J. Appl. Meteorol. 36, 167-182.

De Ridder, K., Lefebre, F., Adriaensen, S., Arnold, U., Beckroege, W., Bronner, C., Damsgaard, O., Dostal, I., Dufek, J., Hirsch, J., Int, Panis L., Kotek, Z., Ramadier, T., Thierry, A., Vermoote, S., Wania, A., Weber, C., 2008. Simulating the impact of urban sprawl on air quality and population exposure in the German Ruhr area. Part I: Reproducing the base state. Atmos. Environ. 42, 7059-7069.

De Ridder, K., Bertrand, C., Casanova, G., Lefebvre, W., 2012. Exploring a new method for the retrieval of urban thermophysical properties using thermal infrared remote sensing and deterministic modelling. J. Geophys. Res. 117. http://dx.doi.org/10.1029/2011JD017194.

De Ridder, K., Viaene, P., Van De Vel, K., Brasseur, O., Cheymol, A., Fierens, F., 2014. The impact of model resolution on simulated ambient air quality and associated human exposure. Atmósfera 27 (4), 403-410.

De Ridder, K., Lauwaet, D., Maiheu, B., 2015. UrbClim - a fast urban boundary layer climate model. Urban Climate 12, 41-58.

Dobler, A., Ahrens, B., 2011. Four climate change scenarios for the Indian summer monsoon by the regional climate model COSMO-CLM. J. Geophys. Res. 116, D24104. http://dx.doi.org/10.1029/2011JD016329.

Doms, G., 2011. A description of the nonhydrostatic regional COSMO-model. Part 1: Dynamics and numerics. Consortium for Small-Scale Modelling. Deutscher Wetterdienst, Offenbach, Germany.

Dousset, B., Gourmelon, F., Laaidi, K., Zeghnoun, A., Giraudet, E., Bretin, P., Maurid, E., Vandentorren, S., 2010. Satellite monitoring of summer heat waves in the Paris metropolitan area. Int. J. Climatol. 31, 313-323.

European Commission, 1994. CORINE Land Cover Technical Guide, EUR 12585 EN. European Commission Publications, Luxembourg, 35pp.

Fischer, E.M., Oleson, K.W., Lawrence, D.M., 2012. Contrasting urban and rural heat stress responses to climate change. Geophys. Res. Lett. 39, L03705. http://dx.doi.org/10.1029/2011GL050576.

Food and Agriculture Organization of the United Nations (FAO), 1998. Digital Soil Map of the World and Derived Soil Properties CD-ROM. FAO, Land and Water Digital Media Series Number 1, ISBN 92-5-104050-8, Rome, Italy.

Gabriel, K.M.A., Endlicher, W.R., 2011. Urban and rural mortality rates during heat waves in Berlin and Brandenburg, Germany. Environ. Pollut. 159, 20442050.

Garratt, J.R., 1992. The Atmospheric Boundary Layer. Cambridge University Press, UK, 316 pp.

Gedzelman, S.D., Austin, S., Cermak, R., Stefano, N., Partridge, S., Quesenberry, S., Robinson, D.A., 2003. Mesoscale aspects of the urban heat island around New York City. Theoret. Appl. Climatol. 75, 29-42. http://dx.doi.org/10.1007/s00704-002-0724-2.

Giannaros, T.M., Melas, D., 2012. Study of the urban heat island in a coastal Mediterranean city: The case study of Thessaloniki, Greece. Atmos. Res. 118, $103-120$.

Grasselt, R., Schuettemeyer, D., Warrach-Sagi, K., Ament, F., Simmer, C., 2008. Validation of TERRA-ML with discharge measurements. Meteorol. Z. 17, 763773.

Grimmond, C.S.B., Blackett, M., Best, M.J., Barlow, J., Baik, J.-J., Belcher, S.E., Bohnenstengel, S.I., Calmet, I., Chen, F., Dandou, A., Fortuniak, K., Gouvea, M.L. Hamdi, R., Hendry, M., Kawai, T., Kawamoto, Y., Kondo, H., Krayenhoff, E.S., Lee, S.-H., Loridan, T., Martilli, A., Masson, V., Miao, S., Oleson, K., Pigeon, G., Porson, A., Ryu, Y.-H., Salamanca, F., Shashua-Bar, L., Steeneveld, G.-J., Tombrou, M., Voogt, J., Young, D., Zhang, N., 2010. The international urban energy balance models comparison project: first results from phase 1. J. Appl. Meteorol. Climatol. 49, 1268-1292.

Grimmond, C.S.B., Blackett, M., Best, M.J., Baik, J.-J., Belcher, S.E., Beringer, J., Bohnenstengel, S.I., Calmet, I., Chen, F., Coutts, A., Dandou, A., Fortuniak, K., Gouvea, M.L., Hamdi, R., Hendry, M., Kanda, M., Kawai, T., Kawamoto, Y., Kondo, H., Krayenhoff, E.S., Lee, S.-H., Loridan, T., Martilli, A., Masson, V., Miao, S., Oleson, K., Ooka, R., Pigeon, G., Porson, A., Ryu, Y.-H., Salamanca, F., Steeneveld, G.J., Tombrou, M., Voogt, J.A., Young, D.T., Zhang, N., 2011. Initial results from phase 2 of the international urban energy balance model comparison. Int. J. Climatol. 31, 244-272.

Gutman, G., Ignatov, A., 1998. Derivation of green vegetation fraction from NOAA/AVHRR for use in weather prediction models. Int. J. Remote Sens. 19 $1533-1543$.

Hamdi, R., Van de Vyver, H., De Troch, R., Termonia, P., 2013. Assessment of three dynamical urban climate downscaling methods: Brussels's future urban heat island under an A1B emission scenario. Int. J. Climatol. http://dx.doi.org/10.1002/joc.3734.

Hazeleger, W., Severijns, C., Semmler, T., Stefanescu, S., Yang, S., Wang, X., Wyser, K., Dutra, E., Baldasano, J.M., Bintanja, R., Bougeault, P., Caballero, R. Ekman, A.M.L., Christensen, J.H., van den Hurk, B., Jiminez, P., Jones, C., Kållberg, P., Koenigk, T., McGrath, R., Miranda, P., Van Noije, T., Palmer, T., Parodi, J.A., Schmith, T., Selten, F., Storelymo, T., Sterl, A., Tapamo, H., Vancoppenolle, M., Viterbo, P., Willén, U., 2010. EC-Earth: a seamless earth system prediction approach in action. Bull. Am. Meteorol. Soc. 91, 1357-1363. http://dx.doi.org/10.1175/2010BAMS2877.1.

Hazeleger, W., Wang, X., Severijns, C., Stefanescu, S., Bintanja, R., Sterl, A., Wyser, K., Semmler, T., Yang, S., van den Hurk, B., van Noije, T., van der Linden, E., van der Wiel, K., 2012. EC-Earth V2.2: description and validation of a new seamless earth system prediction model. Clim. Dyn. 39, 2611-2629.

Ikeda, R., Kusaka, H., 2010. Proposing the simplification of the multilayer urban canopy model: Intercomparison study of four models. J. Appl. Meteorol. Climatol. 49, 902-919.

IPCC, 2012. Managing the Risks of Extreme Events and Disasters to Advance Climate Change Adaptation. A Special Report of Working Groups I and II of the Intergovernmental Panel on Climate Change.

Jaeger, E.B., Anders, I., Luethi, D., Rockel, B., Schaer, C., Seneviratne, S.I., 2008. Analysis of ERA40-driven CLM simulations for Europe. Meteorol. Z. 17, 349367.

Jürges, W., 1924. Der Wärmeübergang an einer ebenen Wand. Beihefte zum, Gesundheits-Ingenieur, vol. 19. Druck und Verlag von R. Oldenbourg, p. 52.

Kanda, M., Kanega, M., Kawai, T., Moriwaki, R., Sugawara, H., 2007. Roughness lengths for momentum and heat derived from outdoor urban-scale models. J. Appl. Meteorol. Climatol. 46, 1067-1079.

Karl, T., Knight, R., 1997. The 1995 Chicago heat wave: how likely is a recurrence? Bull. Am. Meteorol. Soc. 78, 1107-1119.

Kassomenos, P.A., Katsoulis, B.D., 2006. Mesoscale and macroscale aspects of the morning Urban Heat Island around Athens, Greece. Meteorol. Atmos. Phys, 94, 209-218.

Kim, Y.-H., Baik, J.-J., 2005. Spatial and temporal structure of the urban heat island in Seoul. J. Appl. Meteorol. 44, 591-605.

Kusaka, H., Hara, M., Takane, Y., 2012. Urban climate projection by the WRF model at 3-km horizontal grid increment: dynamical downscaling and predicting heat stress in the 2070's August for Tokyo, Osaka, and Nagoya metropolises. J. Meteorol. Soc. Jpn. 90B, 47-63.

Landsberg, H.E., 1981. The Urban Climate. International Geophysical Series, vol. 28. Academic Press, NY, p. 275.

Lauwaet, D., Hooyberghs, H., Maiheu, B., Lefebvre, W., Driesen, G., Van Looy, S., De Ridder, K., 2015. Detailed Urban Heat Island projections for cities worldwide: dynamical downscaling CMIP5 global climate models. Climate 3, 391-415.

Lee, S.-H., Baik, J.-J., 2010. Statistical and dynamical characteristics of the urban heat island intensity in Seoul. Theoret. Appl. Climatol. 100, 227-237.

Lemonsu, A., Kounkou-Arnaud, R., Desplat, J., Salagnac, J.L., Masson, V., 2013. Evolution of the Parisian urban climate under a global changing climate. Climatic Change 116, 679-692. http://dx.doi.org/10.1007/s10584-012-0521-6.

Lynn, B.H., Carlson, T.N., Rosenzweig, C., et al, 2009. A modification to the NOAH LSM to simulate heat mitigation strategies in the New York City Metropolitan Area. J. Appl. Meteorol. Climatol. 48, 199-216. http://dx.doi.org/10.1175/2008JAMC1774.1.

Masson, V., 2000. A physically-based scheme for the urban energy budget in atmospheric models. Bound.-Layer Meteorol. 94, 357-397.

Masson, V., 2006. Urban surface modeling and the meso-scale impact of cities. Theoret. Appl. Climatol. 84, 35-45. http://dx.doi.org/10.1007/s00704-005$0142-3$.

McCarthy, M.P., Harpham, C., Goodess, C.M., Jones, P.D., 2012. Simulating climate change in UK cities using a regional climate model, HadRM3. Int. J. Climatol. 32, 1875-1888. http://dx.doi.org/10.1002/joc2402. 
Meissner, C., Schädler, G., Panitz, H.-G., Feldmann, H., Kottmeier, C., 2009. High-resolution sensitivity studies with the regional climate model COSMO-CLM. Meteorol. Z. 18, 543-557.

Oke, T.R., 1997. Urban climates and global environmental change. In: Thompson, R.D., Perry, A. (Eds.), Applied Climatology: Principles and Practice. Routledge, pp. 273-287.

Oke, T.R., 2002. Boundary Layer Climates. Taylor \& Francis, 464 pp.

Oke, T.R., Johnson, G.T., Steyn, D.G., Watson, I.D., 1991. Simulation of surface urban heat islands under "ideal" conditions at night. Part 2: Diagnosis of causation. Boundary Layer Meteorol. 56, 339-358.

Oleson, K.W., Bonan, G.B., Feddema, J., Vertenstein, M., Grimmond, C.S.B., 2008. An urban parameterization for a global climate model. 1. Formulation and evaluation for two cities. J. Appl. Meteorol. Climatol. 47, 1038-1060.

Oleson, K., 2012. Contrasts between urban and rural climate in CCSM4 CMIP5 climate change scenarios. J. Clim. 25, 1390-1412.

Oleson, K.W., Bonan, G.B., Feddema, J., Jackson, T., 2011. An examination of urban heat island characteristics in a global climate model. Int. J. Climatol. 31, $1848-1865$.

Pielke Sr., R.A., 2002. Mesoscale Meteorological Modeling, second ed. Academic Press, San Diego, 676pp.

Piringer, M., Joffre, S., Baklanov, A., Christen, A., Deserti, M., De Ridder, K., Emeis, S., Mestayer, P., Tombrou, M., Middleton, D., Baumann-Stanzer, K., Dandou, A., Karppinen, A., Burzynski, J., 2007. The surface energy balance and the mixing height in urban areas - activities and recommendations of COST Action 715. Bound.-Layer Meteorol. 124, 3-24.

Rowley, F.B., Algren, A.B., Blackshaw, J.L., 1930. Surface conductances as affected by air velocity, temperature, and character of surface. ASHRAE Trans. 36, 429-446.

Sedlar, J., Hock, R., 2009. Testing longwave radiation parameterizations under clear and overcast skies at Storglaciaren, Sweden. The Cryosphere 3, 75-84.

Smith, T., Zaitchik, B., Gohlke, J.M., 2013. Heat waves in the United States: definitions, patterns and trends. Climatic Change 118, $811-825$.

Sobrino, J.A., Oltra-Carrió, R., Sòria, G., Bianchi, R., Paganini, M., 2012. Impact of spatial resolution and satellite overpass time on evaluation of the surface urban heat island effects. Remote Sens. Environ. 117, 50-56.

Taylor, K.E., Stouffer, R.J., Meehl, G.A., 2012. An Overview of CMIP5 and the experiment design. Bull. Am. Meteorol. Soc. 93, $485-498$.

Van Vuuren, D.P., Edmonds, J., Kainuma, M., Riahi, K., Thomson, A., Hibbard, K., Hurtt, G.C., Kram, T., Krey, V., Lamarque, J.-F., Masui, T., Meinshausen, M., Nakicenovic, N., Smith, S.J., Rose, S.K., 2011. The representative concentration pathways: an overview. Climatic Change $109,5-31$.

Van Weverberg, K., De Ridder, K., Van Rompaey, A., 2008. Modeling the contribution of the Brussels Heat Island to a long temperature time series. J. Appl. Meteorol. Climatol. 47, 976-990.

Wouters, H., Demuzere, M., De Ridder, K., van Lipzig, N.P.M., 2015. The impact of impervious water-storage parametrization on urban climate modelling. Urban Clim. 11, 24-50. 